\title{
Influence of processing conditions on the quality of briquettes produced by recycling charcoal dust
}

\author{
Josephat Kipyegon Tanui ${ }^{1}$ [D $\cdot$ Paul Ndirangu Kioni ${ }^{1} \cdot$ Peter Ngugi Kariuki ${ }^{2} \cdot$ John Mburu Ngugi $^{1}$
}

Received: 16 January 2017 / Accepted: 10 April 2018 / Published online: 17 May 2018

(c) The Author(s) 2018

\begin{abstract}
Physical and thermal properties of briquettes produced by recycling charcoal dust under different processing conditions have been reported in this study. The main aim was to investigate the effects of the binder and processing conditions on the properties of briquettes. The effect of adding molasses binder on combustion properties of the briquette was first assessed. Then by fitting experimental data, mathematical models to predict gross calorific value, ash content, moisture content, relaxed density and shatter index with respect to binder mass fraction, drying temperature and compaction pressure were developed. All briquettes properties were predominantly affected by amount of molasses used. Molasses mass fraction increment in briquette results in significant increment in ash content, moisture content, relaxed density and shatter index and significant reduction in gross calorific value. Drying temperature did not have major influence on briquette properties except moisture content. Compaction pressure (50-150 MPa) used in this study had negligible influences on all briquette properties. Therefore, such high pressure which involves energy consumption is not necessary during production of charcoal dust briquettes. Optimized values of gross calorific value and shatter index were $29.031 \mathrm{MJ} / \mathrm{kg}$ and $80.363 \%$, respectively, for $50 \mathrm{MPa}$ compaction pressure, $29.512{ }^{\circ} \mathrm{C}$ drying temperature and $10 \%$ molasses mass ratio.
\end{abstract}

Keywords Briquettes $\cdot$ Charcoal dust $\cdot$ Molasses binder $\cdot$ Thermal properties $\cdot$ Physical properties

\section{Introduction}

Biomass fuel is the main source of energy for most Kenyan population. In fact, according to Energy Commission of Kenya [1], 70\% of the Kenya energy demand is contributed by biomass and more than $90 \%$ of the rural households depend on it for their energy needs. These fuels are normally used in various forms, viz.; solid wood, wood chips, wood pellets, charcoal, crop residue, sawdust, briquette, etc. Charcoal and firewood are the principal fuels used in Kenya [2, $3]$. Even though there is a large amount of biomass waste generated in Kenya (4.5 million tonnes per year [4]), its usage in the form of briquette fuels is still low [5]. Charcoal dust is among these unexploited resources [2].

Josephat Kipyegon Tanui

josephat.tanui@dkut.ac.ke

1 Department of Mechanical Engineering, School of Engineering, Dedan Kimathi University of Technology, P.O. Box 657-10100, Nyeri, Kenya

2 Department of Chemistry, School of Science, Dedan Kimathi University of Technology, P.O. Box 657-10100, Nyeri, Kenya
In Kenya, charcoal is produced in rural areas and transported to urban area where its consumption rate stands at $82 \%$ [6]. Along charcoal supply chain, some of it ends up being waste in the form of fine char particles (charcoal dust). This waste product arises from handling and transportation of charcoal. They are available in abundance at charcoal vendors. For instance, Fig. 1 shows a photo of charcoal dust dumped outside a charcoal vendor store in Nyeri, Kenya. According to Kenya Forestry Service report [7], charcoal dust generated during charcoal production is between 10 and $15 \%$ of the total charcoal produced. Pure charcoal dust has the same calorific values as the parent charcoal. Therefore, they have potential of supplying more energy in places where they are readily available. They can be used in specialized boilers which are designed to burn pulverized biomass fuel [8]. However, the authors noted that these boilers are not common and the existing ones which are used for pulverized coal combustion need to be redesigned for efficient pulverized biomass combustion. On the other hand, charcoal dust can be used to make briquettes which are then burned in an ordinary stove for small-scale applications. 


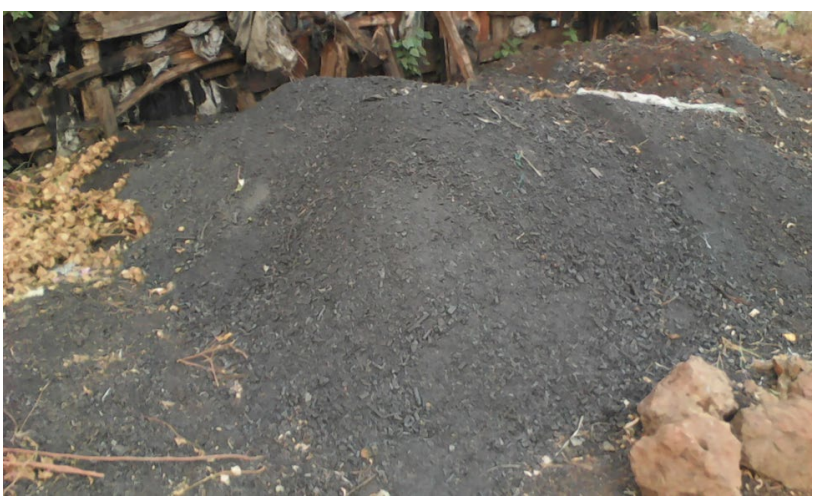

Fig. 1 A photo of charcoal dust dumped outside a charcoal vendor store in Nyeri, Kenya

Briquetting is the process of compressing loose fuel material to form a high densified product. As a result, physical, chemical and combustion properties of the material are much improved [9-11]. In addition, transportation and storage is enhanced. Numerous research [12-16] have been done on briquette production and characterization. A lot of efforts have been made to study briquettes from different sources [17-21]. Properties such as volatile matter, calorific value, relaxed density, compressed density, ash content, durability, fixed carbon, dimensional stability, compressive strength, etc., vary with raw material, binder type, compacting pressure and temperature. Therefore, these properties cannot be generalized. During briquette making, some biomass naturally binds when subjected to favourable temperatures and pressures because they have lignin $[4,22,23]$. However, if these conditions are not met then a binder is required to complete the process. Some of the binders which are normally used include starch, molasses, clay, dung, gum, among others. These binders have impact on briquette properties. For instance, Ngusale et al. [4] reported that charcoal briquettes made from clay and red soil as binders emit a lot of smoke during combustion.

Diversity of raw materials and binders for briquette making complicates its physical, chemical and thermal characterization. Furthermore, properties of a briquette are altered by the ratio of binder to raw material. Even though charcoal dust briquettes have been produced and use in Kenya [4], the effect of various binders and processing conditions such as compression pressures and drying temperature on fuel properties have not been fully assessed. This research is motivated by this fact and the need to identify the binder type together with mixing ratio for optimum properties. Sugar cane molasses, which has relatively good combustion properties as a binder [24] has been used in this study.

The main aim of this study was to investigate the effect of using sugar cane molasses as a binder on the properties of briquette made from recycling charcoal dust. The impact of compaction pressure, drying temperature and binder's level on the physical and thermal properties of the briquette were evaluated. Subsequently, the independent parameters that give optimum briquette's performance in terms of gross calorific value, fixed carbon, ash content, moisture content, relaxed density and shatter index were determined through analysis of variance (ANOVA) and regression analysis (RA). Furthermore, a mathematical model to predict each of these briquette properties as a function of input parameters was developed.

\section{Material and methods}

\section{Material}

Eucalyptus charcoal was obtained from a charcoal vendor in Nyeri, Kenya. The charcoal was grinded into fine particles to represent the charcoal dust. The charcoal dust was sieved with a $2 \mathrm{~mm}$ sized sieve, so that dust with particles less than this size was used in the tests. Raw sugarcane molasses was obtained from a local shop in Nyeri, Kenya.

\section{Briquette production}

An experimental rig, shown in Fig. 2a was designed so that it could be used on a hydraulic press (Tecnotest, Modena Italy) available at civil department, DeKUT. Figure $2 b$ shows a mold that has been mounted on hydraulic press. The internal diameter and length of the mild steel mold was 25 and $100 \mathrm{~mm}$, respectively. A $24.8 \mathrm{~mm}$ diameter by $100 \mathrm{~mm}$ long mild steel shaft was used as a piston. During compression, the mold was placed on a removable plate and the two pieces held together by a compression spring as shown in Fig. 2a. Once the sample was compressed to the required force, the removable plate was removed and the mold placed concentrically on top of ejection guide. The sample was ejected from the mold by applying a small force on it.

Three different ratios by mass of charcoal dust to undiluted sugarcane molasses, according to experimental plans, were prepared for mixture. Since molasses was a small fraction of the total mixture, it was diluted with water $(10 \%$ of the total mixture) to ensure homogeneity in the properties of charcoal/molasses mixture. The percentage of molasses/charcoal dust by mass was set to range between 0 and $10 \%$. For every ratio, $20 \pm 0.1 \mathrm{~g}$ of the mixture was compacted under different pressure, namely, between 50 and $150 \mathrm{MPa}$. The mass of charcoal dust, molasses and mixture were determined using electronic weighing scale TP-B2000 with an accuracy of $0.1 \mathrm{~g}$. A manually operated hydraulic press was used to compact the mixture in the mold. The pressing force was determined using in-build force sensors attached to the punch and the readings obtained on an 
Fig. 2 Schematic diagram of the briquette production mold, hydraulic press and briquette samples
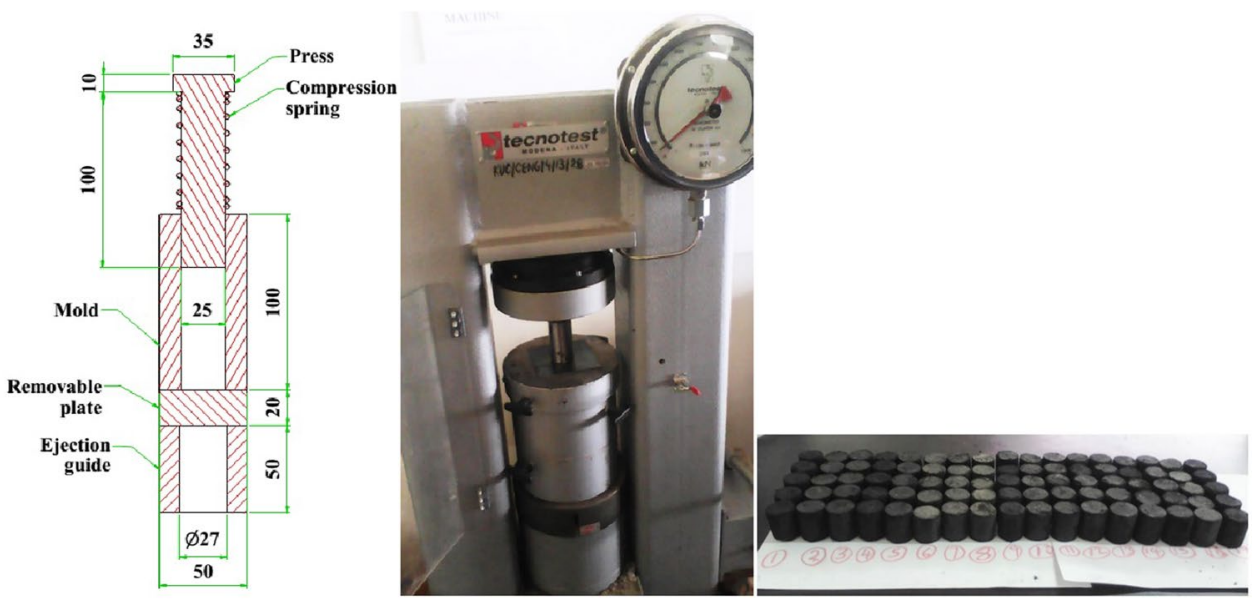

(a) Mold

(b) Hydraulic press

(c) Briquette samples

analogue display. Once the desired force was achieved, the punch was retracted and the briquette ejected immediately from the mold. In total, five sets of 17 samples (according to Box-Behnken Design methodology which is illustrated in Sect. "Design of Experiments") shown in Fig. 2c are produced. Each set was tested for moisture content, ash content, gross calorific value, relaxed density and shatter index, respectively. Each sample was dried on an electric oven at the required temperature, according to the experimental plan, for $2 \mathrm{~h}$.

A different set of briquettes were used to evaluate the effect of binder's level alone on its combustion properties. This set were produced at a pressure of $100 \mathrm{MPa}$ and dried at $25^{\circ} \mathrm{C}$.

\section{Physical properties of briquettes}

\section{Moisture content}

Moisture content of briquettes produced under different conditions was determined in accordance to CEN-TS 147742:2009 standard.

\section{Relaxed density}

Relaxed density, RD, of the sample was determined in accordance to international standard ISO 3131. The weight and volume of the sample was determined after leaving it to dry for 30 days from the production day.

\section{Shatter index}

Durability of the briquette was determined using shatter [13, $22,25]$. Shatter index of the sample was determined by subjecting it to a free fall from a constant height. Each sample was dropped in a metal bucket three times from a height of $1.5 \mathrm{~m}$. The broken pieces were passed through a $1.0 \mathrm{~cm}$ sieve and the retained mass recorded. Detailed description of shatter index calculation can be found [22].

\section{Thermal properties of briquettes}

In this study, the combustion quality of the produced briquettes was evaluated based on gross calorific value, volatile matter, fixed carbon and ash content. Gross calorific value, volatile matter and ash content were determined in accordance to CEN-TS 14918:2009, CEN-TS 15148:2009 and CEN-TS 14775:2009 standards, respectively. Fixed carbon, FC was estimated by difference:

$\mathrm{FC}=100-(\mathrm{VM}+\mathrm{AC})$,

where $\mathrm{VM}$ is the volatile matter and $\mathrm{AC}$ is the ash content.

\section{Design of experiments}

To establish the optimum conditions in terms of compression force, charcoal dust/sugarcane molasses ratio and drying temperature, Box-Behnken Design (BBD) methodology for experiment was used. The aim of using BBD methodology, which is one of the response surface methodology (RSM), was to reduce the cost and the number of experiments and for optimization purpose [26, 27]. In three-level factorial BBD, the number of experiments is according to the equation: $N=2 k(k-1)+c_{\mathrm{p}}$, where $c_{\mathrm{p}}$ is the number of central points, $k$ is the number of factors and $N$ is the number of experiments. Therefore, for three factors used in this study, the total number of experiments was 17;12 experiments for each factor at three levels and five central experiments. As required by BBD, all factors were adjusted at three equally spaced levels $(-1,0,+1)$. The compaction pressure, drying temperature 
and binders weight fraction have been coded as $x_{1}, x_{2}$ and $x_{3}$, respectively. The three levels of these factors are presented in Table 1.

Mathematical models to predict calorific value, ash content, moisture content, relaxed density and shatter index, respectively, as a function of input parameters were to be developed. The general mathematical model for each of these parameters was a second-order polynomial regression model Eq. (2), which was established by fitting the experimental data:

$y=\beta_{0}+\sum_{i=1}^{k} \beta_{i} x_{i}+\sum_{i=1}^{k} \beta_{i i} x_{i}^{2}+\sum_{i=1}^{k} \beta_{i j} x_{i} x_{j}+\varepsilon$,

where $k$ is the number of independent variables, $x_{i}$ and $x_{j}$ are the independent input variable, $y$ is the response variables, $\beta_{0}$ is the constant term, $\beta_{i}$ is the linear parameters coefficient

Table 1 Physical and coded values for input factors

\begin{tabular}{llll}
\hline Input factors & \multicolumn{3}{c}{ Coded values of input factors } \\
\cline { 2 - 4 } & $x_{i, \min }$ & $x_{i, 0}$ & $x_{i, \max }$ \\
& $(-1)$ & $(0)$ & $(+1)$ \\
\hline Compaction pressure, $x_{1}(\mathrm{Mpa})$ & 50 & 100 & 150 \\
Drying temperature, $x_{2}\left({ }^{\circ} \mathrm{C}\right)$ & 25 & 62.5 & 100 \\
Molasses mass, $x_{3}(\%)$ & 0 & 5 & 10 \\
\hline
\end{tabular}

$\beta_{i i}$ is the quadratic parameter coefficient, $\beta_{i j}$ is the interaction parameter coefficient and $\varepsilon$ the experimental residuals.

Design-Expert 10 software package was used to generate the experimental points as per BBD methodology. The experimental points and data are shown in Table 2 Experimental data was used to determine regression model. Furthermore, ANOVA was used to evaluate the statistical significance of the regression model. ANOVA results response variables investigated are shown in Table 3. Compaction pressure, drying temperature and molasses mass are represented as $A, B$ and $C$, respectively, in the design expert software.

\section{Results and discussions}

\section{Effect of binder on briquettes combustion properties}

The effect of the binder on briquettes combustion properties is illustrated in Table 4. The table shows that the binder level has a significant influence on all the combustion properties investigated. An increase in binder level reduces the gross calorific value. This is expected because of the reduction in char fraction which contribute significantly to the gross calorific value of the mixture. It is also observed that volatile matter increases while the fixed carbon reduces as the binder level is increased. This is an indication that molasses has additional volatiles which are non-combustible. This

Table 2 Physical and combustion properties of briquette as a function of input factors

\begin{tabular}{|c|c|c|c|c|c|c|c|c|}
\hline Sample & $\begin{array}{l}\text { Compaction pres- } \\
\text { sure (Mpa) }\end{array}$ & $\begin{array}{l}\text { Drying tem- } \\
\text { perature }\left({ }^{\circ} \mathrm{C}\right)\end{array}$ & $\begin{array}{l}\text { Molasses } \\
\text { mass }(\%)\end{array}$ & $\begin{array}{l}\text { Gross calorific } \\
\text { value }(\mathrm{MJ} / \mathrm{kg})\end{array}$ & $\begin{array}{l}\text { Ash content } \\
(\mathrm{wt} \%)\end{array}$ & $\begin{array}{l}\text { Moisture con- } \\
\text { tent (wt \%) }\end{array}$ & $\begin{array}{l}\text { Relax density } \\
\left(\mathrm{g} / \mathrm{cm}^{3}\right)\end{array}$ & $\begin{array}{l}\text { Shatter } \\
\text { index } \\
(\%)\end{array}$ \\
\hline 1 & 150 & 62.5 & 0 & 29.75 & 1.3 & 11.2 & 1.017 & 34.7 \\
\hline 2 & 50 & 100 & 5 & 27.15 & 1.7 & 9.4 & 0.976 & 82.8 \\
\hline 3 & 100 & 100 & 10 & 27.20 & 3.9 & 11.1 & 1.076 & 94.1 \\
\hline 4 & 100 & 25 & 10 & 28.27 & 4.0 & 16.3 & 1.147 & 66.7 \\
\hline 5 & 50 & 25 & 5 & 29.37 & 2.7 & 16.1 & 1.053 & 57.4 \\
\hline 6 & 150 & 100 & 5 & 27.87 & 2.6 & 10.1 & 1.025 & 57.4 \\
\hline 7 & 100 & 100 & 0 & 29.14 & 1.5 & 8.3 & 0.976 & 23.4 \\
\hline 8 & 100 & 25 & 0 & 30.67 & 1.6 & 14.6 & 1.030 & 32.2 \\
\hline 9 & 100 & 62.5 & 5 & 27.96 & 3.1 & 12.8 & 1.067 & 52.8 \\
\hline 10 & 150 & 25 & 5 & 29.01 & 1.8 & 15.0 & 1.115 & 60.6 \\
\hline 11 & 50 & 62.5 & 0 & 29.73 & 1.3 & 11.4 & 0.935 & 22.6 \\
\hline 12 & 150 & 62.5 & 10 & 27.70 & 4.6 & 13.1 & 1.106 & 61.1 \\
\hline 13 & 100 & 62.5 & 5 & 28.47 & 2.8 & 12.0 & 1.070 & 54.3 \\
\hline 14 & 50 & 62.5 & 10 & 28.55 & 2.8 & 13.0 & 1.081 & 92.7 \\
\hline 15 & 100 & 62.5 & 5 & 28.21 & 2.8 & 12.6 & 1.044 & 53.8 \\
\hline 16 & 100 & 62.5 & 5 & 28.52 & 3.4 & 12.3 & 1.035 & 52.0 \\
\hline 17 & 100 & 62.5 & 5 & 28.33 & 3.0 & 12.0 & 1.030 & 52.2 \\
\hline
\end{tabular}




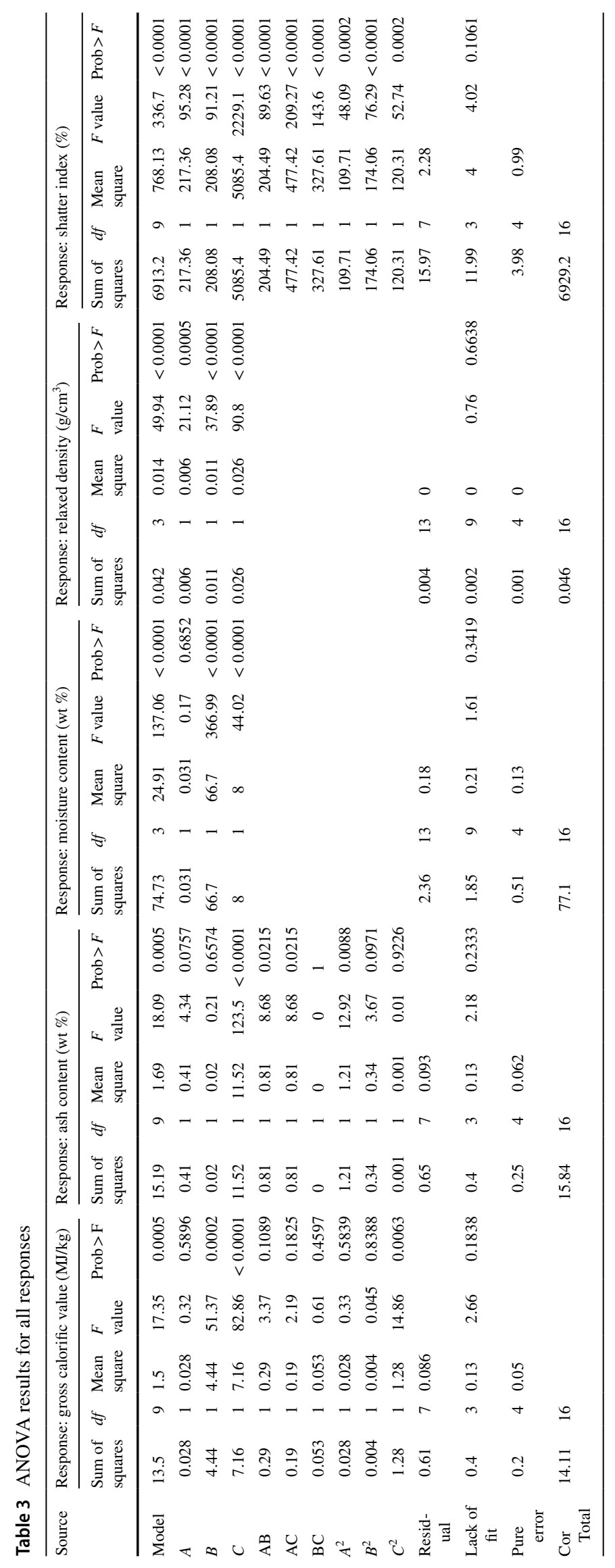


Table 4 Briquettes combustion properties

\begin{tabular}{lllll}
\hline $\begin{array}{l}\text { Molasses level } \\
(\mathrm{wt} \%)\end{array}$ & \multicolumn{3}{l}{ Briquette combustion properties } \\
\cline { 2 - 5 } & Ash content $(\%)$ & Volatile matter $(\%)$ & Fixed carbon (\%) & $\begin{array}{l}\text { Gross calorific } \\
\text { value (MJ/kg) }\end{array}$ \\
\hline 0 & $1.55 \pm 0.03 \mathrm{a}$ & $23.03 \pm 0.04 \mathrm{a}$ & $75.43 \pm 0.02 \mathrm{a}$ & $30.56 \pm 0.02 \mathrm{a}$ \\
2 & $2.10 \pm 0.04 \mathrm{~b}$ & $23.73 \pm 0.09 \mathrm{~b}$ & $74.18 \pm 0.05 \mathrm{~b}$ & $29.85 \pm 0.01 \mathrm{~b}$ \\
4 & $2.73 \pm 0.02 \mathrm{c}$ & $23.92 \pm 0.03 \mathrm{c}$ & $73.35 \pm 0.02 \mathrm{c}$ & $29.25 \pm 0.02 \mathrm{c}$ \\
6 & $2.30 \pm 0.04 \mathrm{~d}$ & $24.40 \pm 0.05 \mathrm{~d}$ & $72.60 \pm 0.03 \mathrm{~d}$ & $28.88 \pm 0.03 \mathrm{~d}$ \\
8 & $3.34 \pm 0.07 \mathrm{e}$ & $24.67 \pm 0.06 \mathrm{e}$ & $72.03 \pm 0.07 \mathrm{e}$ & $28.69 \pm 0.04 \mathrm{e}$ \\
10 & $3.95 \pm 0.05 \mathrm{f}$ & $25.33 \pm 0.02 \mathrm{f}$ & $70.73 \pm 0.03 \mathrm{f}$ & $28.29 \pm 0.03 \mathrm{f}$ \\
$P$ value & 0.042 & 0.021 & 0.028 & 0.037 \\
\hline
\end{tabular}

Data presented in the table are mean values of four replicates. Values in the same column with different alphabet are significantly different at $\alpha=0.05$ using Duncan multiple range test also contributes to the reduction in gross calorific value. The ash content increases with increase in binder level. Some of non-combustible elements present in molasses which do not vaporize remains as ash.

\section{Overall effect of the binder and processing conditions on briquettes properties}

\section{Gross calorific value of briquettes}

Gross calorific values for briquettes produced ranged between 27.15 and $30.67 \mathrm{MJ} / \mathrm{kg}$, which compares well with the values obtained for wood char by other researchers [28-31].

The effect of various factors and their interaction on various briquette properties are shown in Table 3 . It shows that factors $B, C$ and $C^{2}$ are significant model terms for gross calorific value. Therefore, insignificant factors $A C, A B, B C$, $A^{2}$ and $B^{2}$ have been omitted in the model. Even though factor $A$ is not significant, it has not been omitted because it supports mathematical hierarchy.

The mathematical model for gross calorific value as a function of compaction pressure, drying temperature and molasses mass is given by Eq. (3).

$$
\begin{aligned}
\text { Gross calorific value }= & 31.182-1.175 \times 10^{-3} A \\
& -0.019867 B-0.41131 C \\
& +0.022206 C^{2}
\end{aligned}
$$

In this model, $R^{2}$ of 0.92 and adjusted $R^{2}$ of 0.89 were obtained. Figure 3 shows a graphical representation of the model when compaction pressure was kept constant at $100 \mathrm{MPa}$. As depicted by the graph, gross calorific value of briquette was significantly influenced by the amount of molasses added to charcoal dust. Pure charcoal dust has high gross calorific value which decreased as molasses

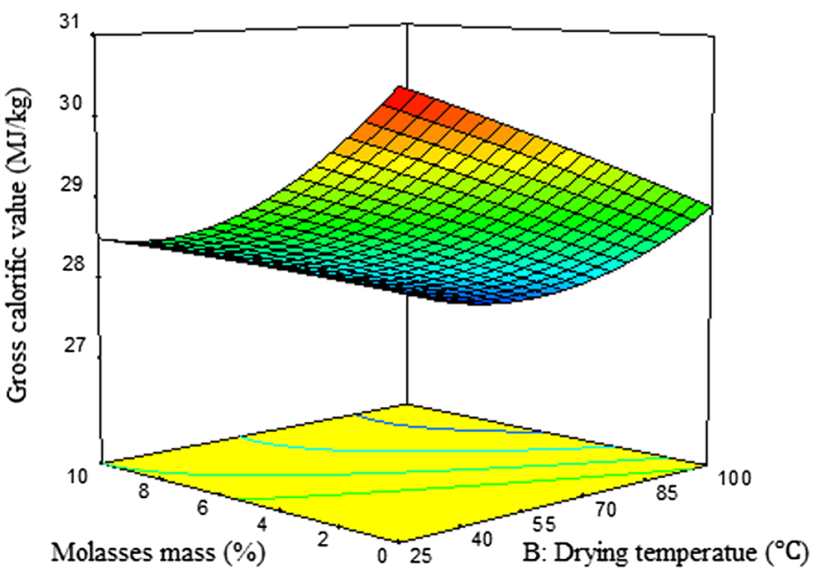

Fig. 3 Gross calorific value as a function of drying temperature and molasses mass when compaction pressure is kept constant at $100 \mathrm{MPa}$

ratio was increased. This was attributed to the fact that molasses is constituted mainly of sucrose [32] which does not have high calorific value as compared to wood char. A similar behavior had also been observed when molasses was used as a binder in rubber wood, corn cob, eucalyptus and bamboo sawdust [20]. On the other hand, it was observed that gross calorific value slightly decreased as drying temperature increased. A maximum gross calorific value of $30.67 \mathrm{MJ} / \mathrm{kg}$ was attained at $0 \%$ molasses mass, $25{ }^{\circ} \mathrm{C}$ drying temperature and $100 \mathrm{MPa}$ compaction pressure, while minimum value of $27.15 \mathrm{MJ} / \mathrm{kg}$ was attained at $5 \%$ molasses mass, $100{ }^{\circ} \mathrm{C}$ drying temperature and $50 \mathrm{MPa}$ compaction pressure. Compaction pressure, which is known to have no impact on calorific value [26] was included in this research to check its possibility of improving mechanical strength of briquettes. Therefore, its influence was negligible as seen in model Eq. (3). 


\section{Ash content of briquettes}

Ash content of the produced briquettes ranged between a minimum of $1.3 \%$ and a maximum of $4.6 \%$. A survey of the literature for eucalyptus wood char (primary raw material for briquettes in this study) ash content reports a minimum of $1.9 \%$ and a maximum of $2.44 \%[29,30,33]$. This indicates that the processing parameters had both negative and positive impact on the ash content of briquettes.

Table 3 shows that the significant model terms for ash content are $A, C, A B, A C, A^{2}$ and $B^{2}$. The model was reduced by removing the other terms $\left(B C\right.$ and $\left.C^{2}\right)$ which are not significant. Factor $B$ was not omitted because of the reason that has been mentioned. Therefore, the final equation in terms of actual factors for predicting ash content was obtained as follows:

$$
\begin{aligned}
\text { Ash content }= & 0.93333+0.023237 A-7.0175 \times 10^{-5} B \\
& +0.06 C+2.4 \times 10^{-4} A B+1.8 \times 10^{-3} A C \\
& -2.13684 \times 10^{-4} A^{2}-2.02105 \times 10^{-4} B^{2} .
\end{aligned}
$$

$R^{2}$ of 0.96 and adjusted $R^{2}$ of 0.93 were obtained for this model. Figure 4 shows a plot of ash content as a function of compaction pressure and molasses mass when drying temperature was kept constant at $62.5^{\circ} \mathrm{C}$. The minimum ash content value occurred at $0 \%$ molasses mass, $62.5^{\circ} \mathrm{C}$ drying temperature and $150 \mathrm{MPa}$ compaction pressure, while maximum value occurred at $10 \%$ molasses mass, $62.5^{\circ} \mathrm{C}$ drying temperature and $150 \mathrm{MPa}$ compaction pressure. Ash content was significantly affected by the amount of molasses used in making briquette. Figure 4 demonstrated an almost linear direct relationship between ash content value and molasses mass fraction. This is attributed to the fact that molasses has

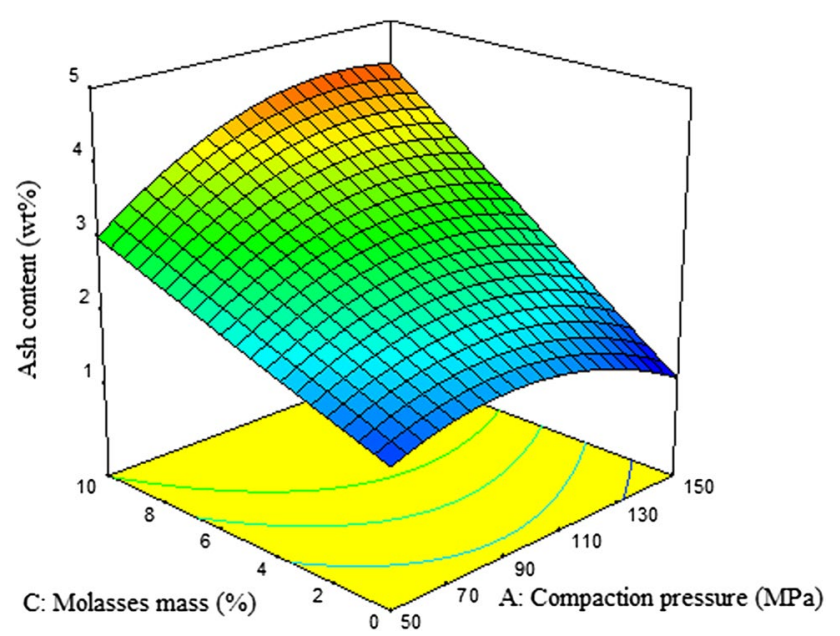

Fig. 4 Ash content as a function of compaction pressure and molasses mass when drying temperature is kept constant at $62.5^{\circ} \mathrm{C}$ a high amount of non-combustible elements, which remain as ash after combustion. The effect of compaction pressure was seen to be moderate with a quadratic curve. At low molasses percentage, ash content increased with increasing compaction pressure from 50 to about $100 \mathrm{MPa}$ and then decreased with pressure increment. As molasses percentage increased a similar behavior was observed, however, the value remained constant after peaking. In this study, it was noted that drying temperature had negligible influence on ash content.

\section{Moisture content of briquettes}

Moisture content of the briquettes obtained ranged between 8.3 and $16.3 \%$. Table 3 indicates that moisture content is a linear relationship of the input factors $A, B$ and $C$, whose model is shown by Eq. (5).

Moisture content $=16.36691-1.25 \times 10^{-3} A-0.077 B+0.2 C$.

$R^{2}$ of 0.97 and adjusted $R^{2}$ of 0.96 were obtained for this model. Shown in Fig. 5 is a graph of moisture content as a function of drying temperature and molasses mass when compaction pressure is kept constant at $100 \mathrm{MPa}$. As expected, drying temperature had a dominating influence on the moisture content of briquettes. It decreased significantly from a maximum of $16.3 \%$ to a minimum of $8.3 \%$ for drying temperature of 25 and $100{ }^{\circ} \mathrm{C}$, respectively. A moderate increase in moisture content with increase in molasses mass was observed. Compaction pressure did not have any influence on moisture content.

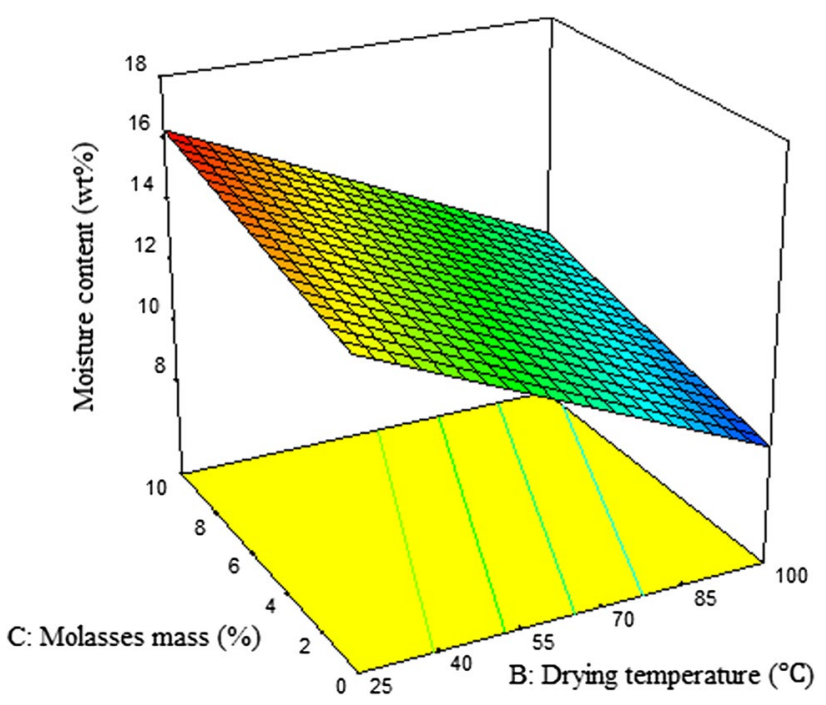

Fig. 5 Moisture content as a function of drying temperature and molasses mass when compaction pressure is kept constant at $100 \mathrm{MPa}$ 


\section{Relaxed density of briquettes}

Relaxed density of briquettes made ranged between 0.935 and $1.147 \mathrm{~g} / \mathrm{cm}^{3}$. As indicated by Table 3 , relaxed density had a linear relationship with factors $A, B$, and $C$ in the form given by Eq. (6).

Relaxed density $=0.99589+5.45 \times 10^{-4} A$

$$
-9.73333 \times 10^{-4} B+0.0113 C \text {. }
$$

$R^{2}$ of 0.92 and adjusted $R^{2}$ of 0.90 were obtained for this case. Shown in Fig. 6 is a graph of relaxed density as a function of drying temperature and molasses mass when compaction pressure was kept constant at $100 \mathrm{MPa}$. Significant increment in relaxed density was observed as molasses was increased from 0 to $10 \%$. This was attributed to relatively high specific gravity of molasses (1.39-1.45 [34]) as compared to that of wood char particle density $\left(0.7-0.9 \mathrm{~g} / \mathrm{cm}^{3}\right.$ [35]). Briquettes made from high molasses mass fraction and dried at low temperatures exhibited the highest relaxed density. Briquettes which are dried at low temperatures retained a high amount of moisture (as discussed in Sect. 3.2.3), which increases briquettes weight and their density. There was negligible influence of compaction pressure on relaxed density. The slight changes in relaxed density with change in pressure show that the briquette had already been compressed beyond rearrangement/fragmentation stage at the lowest pressure (50 MPa). Therefore, the pressures applied was in the plastic deformation range where there are no more internal pores to be filled by the increasing compaction force and the briquette volume remains relatively constant.

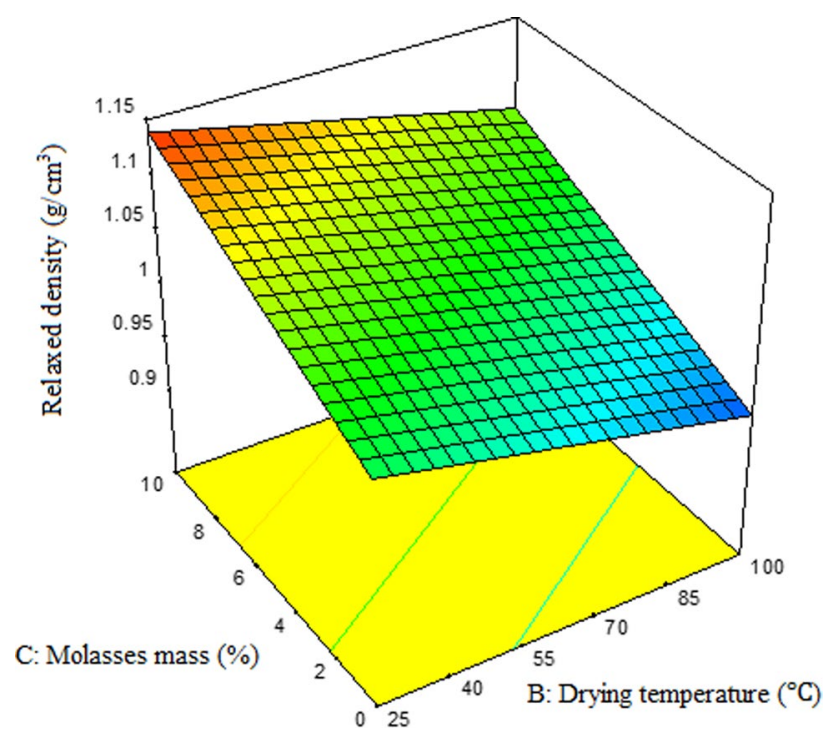

Fig. 6 Relaxed density as a function of drying temperature and molasses mass when compaction pressure is kept constant at $100 \mathrm{MPa}$

\section{Shatter index of briquettes}

Briquettes that were produced had shatter index ranging between 22.6 and $94.1 \%$. According to ANOVA results (Table 3), all factors as well as interactions were significant in the shatter index model. Therefore, the model without reduction is presented in Eq. (7).

$$
\begin{aligned}
\text { Shatter index }= & 32.06072-0.055777 A-0.29551 B+8.53403 C \\
& -3.81333 \times 10^{-3} A B-0.0437 A C+0.048267 B C \\
& +2.0418 \times 10^{-3} A^{2}+4.5721 \times 10^{-3} B^{2}-0.21382 C^{2} .
\end{aligned}
$$

$R^{2}$ of 0.99 and adjusted $R^{2}$ of 0.99 were obtained for this model. Shown in Fig. 7 is a graph of shatter index as a function of drying temperature and molasses mass when compaction pressure is kept constant at $100 \mathrm{MPa}$. Shatter index was significantly changed from 22 to $94.1 \%$ for molasses mass fraction of 0 and $10 \%$, respectively. Drying temperature has no effects on shatter index of briquette made without molasses binder. When the binder was introduced, shatter index slightly increased with drying temperature increment. Its effect is seen to be profound at high molasses mass fraction.

On the other hand, for briquette without binder, shatter index slightly increased with increased in compaction pressure (shown in Fig. 8). However, at high molasses ratio shatter index decreases with increase in compaction pressure. This is contrary to the expectation that high pressure would increase the closeness of the particles and may improve the bonding forces. The sole purpose of including compaction pressure as one of the factors in this study was to check its effect on briquette strength. Therefore, with this regard, it is not desirable to have such a high compaction pressures which increases energy consumption and has little influence on briquette durability and strength.

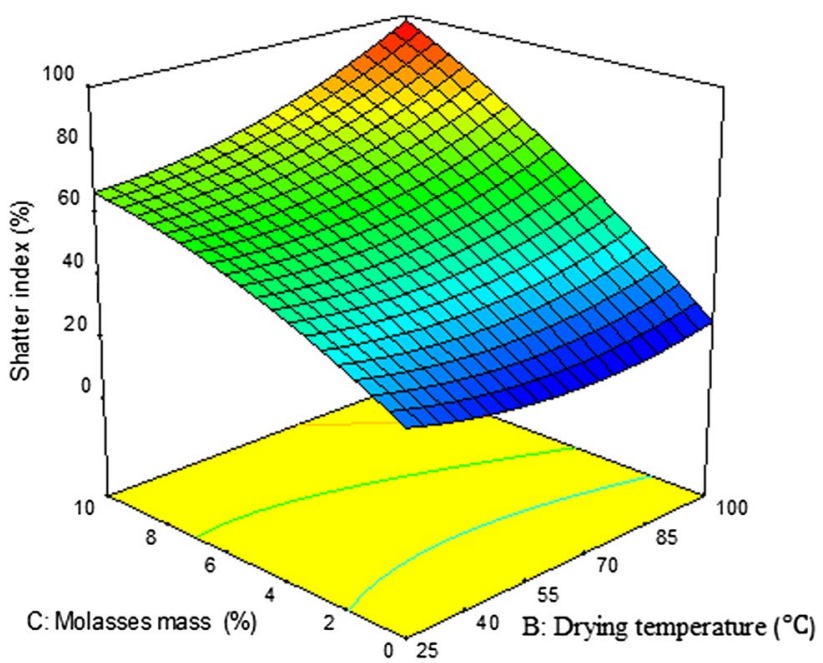

Fig. 7 Shatter index as a function of drying temperature and molasses mass when compaction pressure is kept constant at $100 \mathrm{MPa}$ 


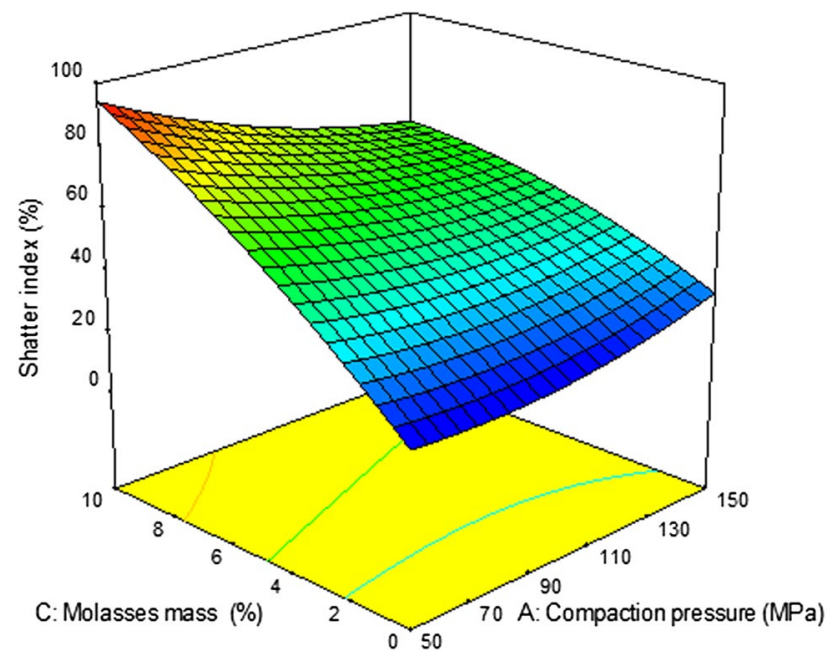

Fig. 8 Shatter index as a function of compaction pressure and molasses mass when drying temperature is kept constant at $62.5^{\circ} \mathrm{C}$

Finally, optimization was done to determine a combination of the three factors that produced briquette with the best properties. In this study, gross calorific value was chosen as an optimization parameter to evaluate the thermal property of briquette, whereas ash content was left out because it had a small range. On the other hand, shatter index was used as optimization parameter for evaluating the briquette strength. By utilizing optimization code available in Design Expert software, it was established that optimized values of gross calorific value and shatter index are $29.031 \mathrm{MJ} / \mathrm{kg}$ and $80.363 \%$, respectively, for $50 \mathrm{MPa}$ compaction pressure, $29.512{ }^{\circ} \mathrm{C}$ drying temperature and $10 \%$ molasses mass ratio. At this point, ash content, moisture content and relaxed density of briquettes are $3.244,16.032 \%$ and $1.107 \mathrm{~g} / \mathrm{cm}^{3}$, respectively.

\section{Conclusion}

In this study, an investigation on the effects of compaction pressure, drying temperature and binder ratio on briquette combustion and physical properties was done. Mathematical models for predicting gross calorific value, ash content, relaxed density, moisture content and shatter index as function of input factors were determined. It was established that molasses mass fraction had predominant effects on all properties investigated. As molasses amount were increased, ash content, moisture content, relaxed density and shatter index were significantly increased while fixed carbon and gross calorific value were significantly reduced. Drying temperature did not have major influence on shatter index, relaxed density, ash content and gross calorific value. However, drying temperature had a dominating influence on the moisture content. Compaction pressure had negligible influences on all briquette properties. Therefore, such high pressure which involves energy consumption is not necessary during production of charcoal dust briquettes. Optimized values of gross calorific value and shatter index were established as $29.031 \mathrm{MJ} / \mathrm{kg}$ and $80.363 \%$, respectively, for $50 \mathrm{MPa}$ compaction pressure, $29.512{ }^{\circ} \mathrm{C}$ drying temperature and $10 \%$ molasses mass ratio.

Acknowledgement Authors would like to acknowledge the department of Research, Technology Management and Community Linkages (RTMCL) of Dedan Kimathi University of Technology for financial support.

\section{Compliance with ethical standards}

Conflict of interest On behalf of all authors, the corresponding author states that there is no conflict of interest.

Open Access This article is distributed under the terms of the Creative Commons Attribution 4.0 International License (http://creativeco mmons.org/licenses/by/4.0/), which permits unrestricted use, distribution, and reproduction in any medium, provided you give appropriate credit to the original author(s) and the source, provide a link to the Creative Commons license, and indicate if changes were made.

\section{References}

1. ERC: "Energy Regulatory Commission - Biomass" (2015). http:// erc.go.ke/index.php?option $=$ com_fsf $\&$ view $=$ faq \& catid $=2 \&$ faqid $=14$. Accessed 17 November 2016

2. Njenga, M., Karanja, N., Karlsson, H., Jamnadass, R., Iiyama, M., Kithinji, J., Sundberg, C.: Additional cooking fuel supply and reduced global warming potential from recycling charcoal dust into charcoal briquette in Kenya. J. Clean. Prod. 81, 81-88 (2014)

3. Karekezi, S.: Renewables in Africa-meeting the energy needs of the poor. Energy Policy. 30(11), 1059-1069 (2002)

4. Ngusale, G.K., Luo, Y., Kiplagat, J.K.: Briquette making in Kenya: Nairobi and peri-urban areas. Renew. Sustain. Energy Rev. 40, 749-759 (2014)

5. Mwampamba, T.H., Owen, M., Pigaht, M.: Opportunities, challenges and way forward for the charcoal briquette industry in SubSaharan Africa. Energy Sustain. Dev. 17, 158-170 (2013)

6. Okello, B.D., O'Connor, T.G., Young, T.P.: Growth, biomass estimates, and charcoal production of Acacia drepanolobium in Laikipia, Kenya. For. Ecol. Manage. 142, 143-153 (2001)

7. KFS: "Analysis of the Charcoal value chain in Kenya" (2016). http://www.kenyaforestservice.org/documents/redd/Charcoal\%20 Value\%20Chain\%20Analysis.pdf. Accessed 23 April 2016

8. Jiménez, S., Remacha, P., Ballesteros, J.C., Giménez, A., Ballester, J.: Kinetics of devolatilization and oxidation of a pulverized biomass in an entrained flow reactor under realistic combustion conditions. Combust. Flame 152, 588-603 (2008)

9. Tabarés, J.L.M., Ortiz, L., Granada, E., Viar, F.P.: Feasibility study of energy use for densificated lignocellulosic material (briquettes). Fuel 79, 1229-1237 (2000)

10. Kaliyan, N., Morey, R.V.: Natural binders and solid bridge type binding mechanisms in briquettes and pellets made from corn stover and switchgrass. Bioresour. Technol. 101, 1082-1090 (2010) 
11. Panwar, V., Prasad, B., Wasewar, K.L.: Biomass residue briquetting and characterization. J. Energy Eng. 137, 108-114 (2011)

12. Yumak, H., Ucar, T., Seyidbekiroglu, N.: Briquetting soda weed (Salsola tragus) to be used as a rural fuel source. Biomass Bioenerg. 34, 630-636 (2010)

13. Obi, O.F.: Evaluation of the effect of palm oil mill sludge on the properties of sawdust briquette. Renew. Sustain. Energy Rev. 52, 1749-1758 (2015)

14. Wilaipon, P.: The effects of briquetting pressure on banana-peel briquette and the banana waste in Northern Thailand. Am. J. Appl. Sci. 6, 167-171 (2009)

15. Obernberger, I., Thek, G.: Physical characterisation and chemical composition of densified biomass fuels with regard to their combustion behaviour. Biomass Bioenerg. 27, 653-669 (2004)

16. Kaliyan, N., Morey, R.V.: Factors affecting strength and durability of densified biomass products. Biomass Bioenerg. 33, 337-359 (2009)

17. Sotannde, O.A., Oluyege, A.O., Abah, G.B.: Physical and combustion properties of briquettes from sawdust of Azadirachta indica. J. For. Res. 21, 63-67 (2010)

18. Teixeira, S.R., Pena, A.F.V., Miguel, A.G.: Briquetting of charcoal from sugar-cane bagasse fly ash (scbfa) as an alternative fuel. Waste Manag. 30, 804-807 (2010)

19. Unpinit, T., Poblarp, T., Sailoon, N., Wongwicha, P., Thabuot, M.: Fuel properties of bio-pellets produced from selected materials under various compacting pressure. Energy Procedia 79, 657-662 (2015)

20. Thabuot, M., Pagketanang, T., Panyacharoen, K., Mongkut, P., Wongwicha, P.: Effect of applied pressure and binder proportion on the fuel properties of holey bio-briquettes. Energy Procedia 79, 890-895 (2015)

21. Mitchual, S.J., Frimpong-Mensah, K., Darkwa, N.A., Akowuah, J.O.: Briquettes from Maize Cobs and Ceiba Pentandra at room temperature and low compacting pressure without a binder". Int. J. Energy Environ. Eng. 4, 38 (2013)

22. Antwi-Boasiako, C., Acheampong, B.B.: Strength properties and calorific values of sawdust-briquettes as wood-residue energy generation source from tropical hardwoods of different densities. Biomass Bioenerg. 85, 144-152 (2016)

23. Moreno, A.I., Font, R., Conesa, J.A.: Physical and chemical evaluation of furniture waste briquettes. Waste Manag. 49, 245-252 (2015)
24. Jittabut, P.: Physical and thermal properties of briquette fuels from rice straw and sugarcane leaves by mixing molasses. Energy Procedia 79, 2-9 (2015)

25. Yank, A., Ngadi, M., Kok, R.: Physical properties of rice husk and bran briquettes under low pressure densification for rural applications. Biomass Bioenerg. 84, 22-30 (2016)

26. Lela, B., Barišić, M., Nižetić, S.: Cardboard/sawdust briquettes as biomass fuel: physical-mechanical and thermal characteristics. Waste Manag. 47, 236-245 (2016)

27. Bezerra, M.A., Santelli, R.E., Oliveira, E.P., Villar, L.S., Escaleira, L.A.: Response surface methodology (RSM) as a tool for optimization in analytical chemistry. Talanta 76, 965-977 (2008)

28. Motghare, K.A., Rathod, A.P., Wasewar, K.L., Labhsetwar, N.K.: Comparative study of different waste biomass for energy application. Waste Manag. 47, 40-45 (2016)

29. Pohlmann, J.G., Borrego, A.G., Osório, E., Diez, M.A., Vilela, A.C.F.: Combustion of eucalyptus charcoals and coals of similar volatile yields aiming at blast furnace injection in a $\mathrm{CO}_{2}$ mitigation environment. J. Clean. Prod. 129, 1-11 (2016)

30. Pohlmann, J.G., Osório, E., Vilela, A.C.F., Diez, M.A., Borrego, A.G.: Pulverized combustion under conventional $\left(\mathrm{O}_{2} / \mathrm{N}_{2}\right)$ and oxy-fuel $\left(\mathrm{O}_{2} / \mathrm{CO}_{2}\right)$ conditions of biomasses treated at different temperatures. Fuel Process. Technol. 155, 174-182 (2016)

31. McNamee, P., Darvell, L.I., Jones, J.M., Williams, A.: The combustion characteristics of high-heating-rate chars from untreated and torrefied biomass fuels. Biomass Bioenerg. 82, 63-72 (2015)

32. Weifeng, L.I., Suhua, M.A., Shengbiao, Z., Xiaodong, S.: Physical and chemical studies on cement containing sugarcane molasses. J. Therm. Anal. Calorim. 118, 83-91 (2014)

33. Pastor-Villegas, J., Pastor-Valle, J.F., Rodríguez, J.M.M., García, M.G.: Study of commercial wood charcoals for the preparation of carbon adsorbents". J. Anal. Appl. Pyrolysis. 76, 103-108 (2006)

34. Olbrich, H.: "The molasses," Biotechnol. Kempe GmbH (2006)

35. Humphreys, F.R., Ironside, G.E.: Charcoal from New South Wales Species of Timber. (1977) http://www.dpi.nsw.gov.au/_data/asset s/pdf_file/0004/389722/Charcoal-from-NSW-Species-of-Timbe r-2nd-Edition.pdf. Accessed 21 Nov 2016

Publisher's Note Springer Nature remains neutral with regard to jurisdictional claims in published maps and institutional affiliations. 